\title{
Ellipsis
}

2018

\section{A Break from the Roots: Conjuring Radical Empathy through the Image of the Self-as-Tree in Chesnutt \& Zitkala-Sa}

Christine Baniewicz

University of New Orleans

Follow this and additional works at: https://scholarworks.uno.edu/ellipsis

\section{Recommended Citation}

Baniewicz, Christine (2018) "A Break from the Roots: Conjuring Radical Empathy through the Image of the Self-as-Tree in Chesnutt \& Zitkala-Sa," Ellipsis: Vol. 45 , Article 13.

DOI: https://doi.org/10.46428/ejail.45.13

Available at: https://scholarworks.uno.edu/ellipsis/vol45/iss1/13

This Essay is brought to you for free and open access by the Department of English and Foreign Languages at ScholarWorks@UNO. It has been accepted for inclusion in Ellipsis by an authorized editor of ScholarWorks@UNO. For more information, please contact scholarworks@uno.edu. 


\section{A Break from the Roots: Conjuring Radical Empathy through the Image of the Self-as-Tree in Chesnutt \& Zitkala-Sa}

Winner of the Malcolm Magaw Prize

The word "radical" has not always meant what it means to most readers today. Unless encountered in esoteric texts on medicine, horticulture, or astrology, the word "radical" in modern parlance is often used to describe measures considered extremely politically or socio-economically progressive, as well as the people who advocate for them. However, this meaning did not come into popular usage in the United States until the latter half of the 19th century. Before then, the word had to do with roots. British uses of "radical" as adjective date back to 13th century, where it meant "of or connected to the root of a plant." Even earlier, Latinate versions of the word similarly had radicalis meaning "relating to or forming the root, original, primary" (Radical). Our modern understanding of the word, then, has everything to do with the idea of political and socioeconomic change from the roots, a concept that draws much of its power from the word's deep, longstanding association with plants and trees.

At the same time the word "radical" was beginning to take on new meaning in the United States, two writers began writing and publishing literature that, more or less overtly, advocated for the most rootless and dispossessed groups of people in the country. Zitkala-Sa, a Sioux writer born in 1876 on a reservation in South Dakota, was a tireless organizer for indigenous rights, and her adulthood was marked by both political activity and writing that affirmed her support of "tribal nationalism" (Hafen 199). Charles Chesnutt, by contrast, was an African-American writer of mixed race with slaves in his lineage whose late-19th-century essays and fiction held that "whiteness was a cultural fiction" (Tunc 677), a concept that more than a hundred years later is still considered quite radical by much of the population.

Both Zitkala-Sa and Chesnutt, variously included in and omitted from the hotly contested category of 19th-century American regionalism, wrote work that stands in marked contrast to other writers within the genre like Sarah Orne Jewett, Grace King and Hamlin Garland. These regionalist writers, Amy Kaplan argues, often enacted "a willed amnesia about [the] founding conflicts" of the nation, including both the massacres of indigenous peoples and the violent legacy of slavery (Kaplan 241-242). 
Zitkala-Sa and Chesnutt's writing, however, resists this forgetfulness. The stories included in Chesnutt's Conjure Tales and, later, The Wife of His Youth direct readers to consider the suffering African Americans endured under slavery and its aftermath. Similarly, Zitkala-Sa's autobiographical accounts of her extreme misery, alienation and sense of loss as she came of age in an assimilatory boarding school in Indiana explicitly reference the "paleface" colonizers and their theft of land and resources from her people (Impressions 545). Their writing stands in marked contrast to the claims of many of their American contemporaries and predecessors, writers like Nathaniel Hawthorne who, in 1860, bemoaned how difficult it was to write "Romance" stories:

... about a country where there is no shadow, no antiquity, no mystery, no picturesque and gloomy wrong, nor anything but a commonplace prosperity, in broad and simple daylight, as is happily the case with my dear native land (qtd. Holman 27).

In contrast to Hawthorne's sunny take on the nation's past, and many white regionalist writers' tendencies to omit or romanticize it, Chesnutt and Zitkala-Sa remind readers of the "gloomy wrongs" at the root of the nation's founding.

In addition to this eye towards the more painful aspects of our nation's past, both writers describe in their work characters who have experienced a traumatic break in the bond with their mothers and/or ancestors. In Chesnutt's "Po' Sandy" from Conjure Tales, Sandy's mother is not present, likely because he was sold away from her, or she was killed, or some other violence beset her via slavery. In Zitkala-Sa's case, much of her writing deals explicitly about her feelings of great pain traceable to her physical and spiritual separation from her mother.

Both Chesnutt (in the story "Po' Sandy" from Conjure Tales) and Zitkala-Sa express this break in the bond to the mother and/or their ancestral roots in general by conjuring the image of the self as a tree that undergoes a break from its roots, ultimately transforming from a living thing into an undead, disfigured, naked version of itself, haunted by the spirit of the life it had before. In the case of Po' Sandy, the transformation is literal within the fantastical world of the conjure tale: Sandy's wife Tenie turns him into a pine tree to spare him the pain of being loaned out again and again to his master's friends and family. For Zitkala-Sa, the image of self-as-tree is figurative, a powerful simile she draws at the end of her essay, "An Indian Teacher Among Indians," and one that builds off the subtly anthropomorphized telephone poles and the fantastic visions of apple trees that appear in her earlier essays, "Impressions of an Indian Childhood" and "School Days."

Ultimately, both Chesnutt and Zitkala-Sa use the image of the self-as-tree to inspire in readers what journalist Isabel Wilkerson calls "radical empathy." Before defining the term as she conceives of it, it's worth noting how often empathy is cited by scholars of regionalism as a defining characteristic of the literature. Judith Fetterley and Marjorie Pryse introduce their anthology of American Women Regionalists by 
elaborating on how each of the anthologized writers worked to "enlarge the hearts and perspectives of their readers" by means of crafting "empathic experience[s] in which [characters] gain an insider's perception of what it feels like to be an outsider" (xviii). For evidence, they cite Jewett's "The Circus at Denby," in which two young women encounter an overweight woman in the freak show at the circus and, upon hearing part of her sad tale, are moved to feel "dismal" for a while. However, before long, the two girls begin "to feel merry again" (195) and their vacation continues. While their encounter may have inspired a fleeting empathy, it did not invoke a particularly radical shift in understanding for the tourists - nor, I'd argue by extension, for readers.

However, Zitkala-Sa and Chesnutt encouraged radical empathy with their writing, which, according to Wilkerson, is different than the kind of empathy that arises from simply imagining yourself "in someone else's shoes." Rather, she contends that radical empathy "requires you know enough about this other person that you can imagine what it is like for them in that situation. The goal is to picture yourself, not as you, but as that person experiencing what they're experiencing" (emphasis mine). Rather than focusing on the gaze of the insider as it's directed towards an outsider, a technique Fetterley and Pryse call shifting the "center of perception" (xviii), Zitkala-Sa and Chesnutt invoke radical empathy by first including enough information about the main characters - their painful pasts, frightening presents and uncertain futures - that the reader might be able to imagine what life is like for those characters. Second, in the texts "Po' Sandy" and "An Indian Teacher Among Indians," they use the image of the self-astree to model the practice of radical empathy for the reader. Their characters do not simply "shift their center of perception" to the tree by imagining what it is like to be uprooted and dismembered; they actually transform themselves into and feel through the trees - living beings that are, after all, even more vulnerable to sudden death and violent uprooting than we are.

Before examining the writing itself, it is useful to consider the historical context within which any late 19th-century American writer, radical or not, would have been living and writing. In his article, "Reading Tree in Nature's Nation," Daegan Miller argues for a "peculiarly American sylvan literacy" by considering the important role trees played in the daily lives of Americans living in almost any region of the contiguous United States during that time period. Until the invention of plastic, in fact, trees and the products made from them - shingles, firewood, false teeth, wagon wheels and plank roads and bed frames - touched nearly every aspect of human life (1121). It is easy for modern readers, immersed as we are in the world of plastics, to forget that trees and the products made from them would have had a powerful impact on the 19thcentury reader, if only for their ubiquity.

Trees also grew, towards the middle of the century, to take on a specifically nationalistic meaning. On the western frontier, settlers could claim a plot of land by 
seeding an apple orchard there, helping apple trees to become a symbol of national progress (Miller 1125). In the eyes of a writer like Zitkala-Sa, such trees would thus also come into close association with her people's dispossession by white colonizers. Additionally, American artists began arguing that "the most distinctive, and perhaps most expressive, characteristic of American scenery is its wildness" and "extensive forests" (qtd. Miller 1122). Horticulturist D.J. Browne wrote, in 1832, that "the trees of our country recall the idea of it in the most forcible manner...the village elm, the wellknown oak, or the unchanged pine of New England" (qtd. Miller 1122). Indeed, as the last quotation implies, specific trees not only evoked a transcontinental sense of American identity during the geographically fractious era following the Civil War and the acquisition of land in both Louisiana and California, they were often simultaneously associated with specific regions within the nation.

In building a case for the regional associations given to specific trees, Miller describes the popular collection, in the 19th century, of "souvenir envelopes, many of which depicted resonant patriotic scenes." One such envelope, circa 1861-1865, depicts a pine tree decapitating a palm tree with a snippet of verse from Oliver Wendell Homes's poem, "A Voice from the Loyal North." Miller writes,

To nineteenth century Americans, the bioregional cultural allusions would have been immediate: since at least the late seventeenth century, white pines had stood for new England... while palms stood for the South, especially the Palmetto State, South Carolina - the first state to secede from the Union. (1115)

Such evidence of trees functioning as popular emblems to political causes would not have escaped the knowledge of writers like Zitkala-Sa and Charles Chesnutt. Like all writers producing work for wide audiences (both had their stories published in the prestigious Atlantic Monthly), they would surely have been savvy to the regionallyspecific and politically charged connotations of the trees they chose to write about.

"Po' Sandy" was among the first three of Chesnutt's Conjure Tales to make their way into print in the late 1880s. Unlike later stories, in which Chesnutt employs a grim realism to paint the dark contours of the color line and its consequences in postbellum America, "Po' Sandy" and the other Conjure Tales employ literary conventions that would have been quite familiar to readers of popular southern regionalist stories of the time. According to Andrews' introduction to the Penguin Classic collection of these stories, Chesnutt employs dialect and "the folkways of southern black people" much in the vein of the popular Uncle Remus stories (ix). Through the frame narrator John, a white Northerner come down to North Carolina for his wife's health and to make his fortune cultivating grapes, we come to know Julius McAdoo, a former slave born and raised on the plantation with seemingly endless knowledge of the history of the place and a gift for storytelling. In each of the loosely interconnected Conjure Tales, Julius tells 
a story of plantation life during slavery. These stories are full of fantastical transformations, as slaves conjure and bewitch themselves and the living things around them on the plantation in order to achieve various ends. In "Po' Sandy," this "goophering" involves the eponymous hero, Sandy, turning into a pine tree with this help of his wife, Tenie.

In "Po' Sandy," Julius tells John and his wife Annie the tale of Sandy, a slave on one of the old nearby plantations. Hardworking and industrious, Sandy comes to be his master's prize slave. His reward for this reputation, however, is to be loaned out again and again to the master's children, forced to travel to other plantations so often that he "did n' hardly knowed whar he wuz gwine ter stay fum one week's een' term de yuther" (16). As Tyler notes in his discussion of the tale, "Sandy's master figuratively pulls him apart [to honor] his children's wishes" (41). During one of Sandy's many periods of service off the plantation, his master trades his wife away for another slave; he offers Sandy a dollar in exchange for any unhappiness this "swap" may have caused him. Ultimately, it is this cruel marital separation, and the looming possibility of losing his "replacement wife," Tenie, that spurs Sandy to take action on his own behalf (Tyler 41). He bemoans his emotional and physical exhaustion at being cast about to Tenie. "I wisht I wuz a tree," he says. "...er sump'n w'at could stay on de plantation fer a w'ile" (17). Tenie then reveals herself as a conjure woman and agrees to transform him into a pine tree. "You won't hab no mouf ner years," she warns. "But I kin turn you back oncet in a w'ile, so you kin git sump'n ter eat, en hear w'at's gwine on." (18) This pine tree-though mouthless, earless, and senseless - becomes an expressive vessel in Chesnutt's hands. More than a mere symbol, the tree allows Sandy (temporarily, at least) to express, through his radical transformation, a profound desire for rootedness, familial love and freedom.

It's worth noting that Chesnutt's choice of the pine tree for this goopher was no coincidence. As the mid-century souvenir envelope reveals, pines already were strongly associated with the Yankee North. Their association, however, is even more aged and complex; according to Miller, "though the white pine may have symbolized New England, the king, or even American Indians to many Euro-Americans, the Iroquois saw the tree as a covenant that tied two people together." He references the Mohawk peace agreement of 1684, whereupon a white pine was planted to formalize "not only peace, but to a mutually agreed-upon Mohawk presence." (1132). Sandy's pine tree, then, takes on a nuanced symbolic meaning in this historical context. Like the Iroquois peace pine, Sandy's presence on the plantation as a tree can be read as a plea for peaceful co-existence between black and white people in the south. Additionally, the shelter and escape from suffering it provides Sandy is analogous to the assistance often provided to black fugitive slaves from indigenous people (Di Silvestro 29). Sandy's pine tree, in this way, takes on evocative elements of sanctuary and refuge that gain power 
from the tree's longstanding association both with native people and the abolitionist north.

However, even as a tree, Sandy does not wholly escape pain. He remains "arboreally vulnerable," his bark penetrated by the bore of a woodpecker and peeled back by a slave come to harvest turpentine (Masiki 369). This latter abuse results in "a big skyar on his lef' leg, des lack it be'n skunt" (19). Turpentine, a chemical used to strip pigment from painted surfaces, does double-duty here in the story, likely alluding to the painful process of assimilation to whiteness in store for African Americans who sought the freedom "to lib lack w'ite folks" after the Civil War (19). This theme comes into sharper focus in Chesnutt's later stories of the color line, like "Wife of His Youth;" however, the reference made in "Po' Sandy" to the skinned appearance of Sandy's leg is no accident. Though subtle, Chesnutt cautions against the attempt of postbellum African Americans to strip the color from themselves in order to pass, as such attempts ultimately result in wounds and scars.

Charles Chesnutt was also not blind to the fact that trees truly were vulnerable in the Reconstruction-era south, and that their vulnerability to the influx of northern capitalist lumber interests could serve as a cognate for the simultaneous exploitation of black labor in the region. As Masiki notes, in the 1870s and ' 80 s:

...millions of acres of federal forest land in the South were claimed...by lumber companies and Northern speculators for as little as \$1.25 an acreland that under a different political scenario would rightly have gone to freedmen. (qtd. 371)

He goes on to note that the thirty years of massive deforestation in the South that elapsed between 1880 and 1910 were "coterminous with the greatest number of African American lynchings in U.S. history" (371). Chesnutt skillfully knits together these two histories of violence in the figure of the anthropomorphic pine tree. The kinship between these two human and non-human living beings is unexpected but poignant. Readers who might otherwise feel unmoved by the plight of former slaves may be swayed to empathize by the clear, palpable portrayal of the violation the tree endures at the sawmill. Likewise, readers without any particular environmental ethos are encouraged to feel human sympathy for the suffering of the tree by virtue of the human qualities it takes on through Sandy. Thus, in this one figuration, Chesnutt manages to make a moving argument against the violent destruction of both the human and natural world, under the Confederate regime as well as during the supposedly peaceful Reconstruction Era.

The refuge from slavery offered Sandy by his transformation into a tree, however, is short-lived. Before he and Tenie are afforded the opportunity to escape the plantation together as goophered foxes, Sandy's master decides to build a new kitchen. He selects Sandy's pine tree for this purpose, and proceeds to chop it down. Tenie, having been lent out away from the plantation, is not there to prevent the master's men; 
however, the pine tree resists hardily. For a full page, in fact, Chesnutt draws out the grisly details, describing the tree's "creakin', en shakin', en wobblin'" as the men attempt to chop it down and haul it down the plank road to the sawmill (20). Alluding directly to the shackles of slavery, Chesnutt describes the tree breaking loose from "de chain" and rolling away multiple times on the way to the sawmill. Most disturbingly, perhaps, is the "moanin' and groanin"' of the log as it's worked through by the "one er dese yere ole-timey, up-en-down saws" (21). These graphic details point directly towards the violent death and dismemberment a fugitive slave would have received as punishment in the antebellum south (Masiki 371-372). This graphic violence against black people, so endemic to both the antebellum and postbellum South, was rarely taken on directly in literature of the time. However, by allowing the fantastical aspect of the story to provide distance, Chesnutt helps "the reader confront and come to terms with the physical and psychological destruction slavery wreaked on black minds, bodies, and souls" (Masiki 372). He gets away with showing us the gory, socially taboo dismemberment of a fugitive slave by ostensibly only showing us a far more acceptable, even commonplace event - the chopping down of a tree.

Zitkala-Sa was born in Yankton, South Dakota in 1876, the same year that Crazy Horse defeated Custer's U.S. forces in the Black Hills at the Battle of Little Big Horn (Hafen 199). She lived with her mother on the reservation until she was eight years old, at which point she left to attend White's Indiana Manual Labor Institute in Wabash, Indiana, one of the many boarding schools for indigenous children scattered all over the country at the time. Zitkala-Sa wrote of her experiences first attending these schools, and later teaching for them, publishing autobiographical essays in 1900 in the Atlantic Monthly titled "Impressions of an Indian Childhood," "School Days," and "An Indian Teacher Among Indians."

According to Fetterley and Pryse, Zitkala-Sa was critical of "the assimilation policies of the Indian boarding schools" in her writing (533), describing with unflinching honesty and detail the brutal, humiliating and dehumanizing treatment she received at the hands of the teachers and administrators. In "School Days," she writes of being "dragged out" of her hiding place under a bed and "tied fast in a chair" to have her braids cut off, "the cold blades of the scissors against my neck" (551). Later, she overhears a friend beaten brutally by a teacher due to a misunderstanding in language, the "poor frightened girl shriek[ing] at the top of her voice" (552). "The melancholy of those black days," writes Zitkala-Sa, "has left so long a shadow that it darkens the path of years that have since gone by" (555). The tremendous detail Zitkala-Sa includes in her writings for the Atlantic gave its mostly white readership access to information about the everyday suffering of indigenous people they otherwise would not have otherwise had. This information, in turn, might inspire a truly radical empathy "for those ears that bent with compassion to hear it" (555), since it allowed readers to 
understand the struggles of an indigenous woman from her own point of view, rather than distilled through a white intermediary character, as was often the case in regionalist literature written by white authors about marginalized people. The lack of intermediary, along with the great wealth of details used by Zitkala-Sa in her work, translated into a collection of essays that promotes radical empathy to a degree unparalleled by even Chesnutt's work.

Throughout all three essays, Zitkala-Sa weaves in imagery around both apple trees and telegraph poles. The former are used by the "paleface missionaries" to lure Zitkala-Sa and her friends out east, where supposedly they "could reach out [their] hands and pick all the red apples [they] could eat. I had never seen apple trees...I was eager to roam among them" (Impressions 546). Red apples, after all, were not indigenous to North America like their cousin, the crab apple, and came along with the settlers to the New World (Miller 1123). As such, the apple tree works as a symbol of the colonizers in these essays, a tempting fantasy of abundance and sweetness that never comes to fruition in reality. Despite the promises of the missionaries, Zitkala-Sa never once catches a glimpse of a red apple tree-instead, upon arrival at the "land of apples," she is greeted by "bitter-cold," thick snow, and bare trees (School 549). As the story progresses, it becomes clear that the red apples were used merely as bait, an empty promise, a temptation.

Zitkala-Sa was certainly also aware of the Biblical associations between the apple tree and the Tree of Knowledge, the forbidden fruit tree with its tempting apples, the eating of which led Adam and Eve to be cast out of Eden forever. In "Impressions of an Indian Childhood," she describes the Eden-like world she lived in with her mother before leaving it for the land of red apples. According to her, childhood on the reservation was full of "joyous relief in running loose" and playing with her friends, finding and eating the abundance of edible roots and plants, "nature's rockcandy" (539540). She describes herself as happily un-self-conscious, "keenly alive to the fire within." (535). However, along with Zitkala-Sa's acceptance of the missionaries' offer of "big red apples" comes a desire for money and "an ambition for Letters" (546). These new, adult, Earthly attachments act as a cognate for the knowledge and selfconsciousness that came to Adam and Eve after taking the apple from the snake and discovering themselves naked, cold and alone. By drawing such clear parallels between her story and a well-known Biblical tale, Zitkala-Sa draws her readers into what would otherwise be an unfamiliar world by giving them a familiar frame of reference for it.

Another important sylvan signifier in Zitkala-Sa's essays is the telegraph pole. At the beginning of "The School Days of an Indian Girl," she describes them as an eightyear-old would, as "poles...planted by white men." She goes on to describe her curiosity about these poles, saying that often she had stopped to "hold [her] ear against the pole, and, hearing its low moaning, [she] used to wonder what the paleface had done to hurt it. (548) This subtle anthropomorphizing figuration, much like Chesnutt's 
description of the "moanin' and groanin'" of the pine tree, works on multiple levels. First, it casts a sense of foreboding as it foreshadows the "hurt" that Zitkala-Sa is about to receive from the paleface school teachers. Secondly, it sets up the powerful extended simile that comes at the end of "An Indian Teacher Among Indians," where Zitkala-Sa returns to the image of the telegraph pole, this time as a representation of herself:

Like a slender tree, I had been uprooted from my mother, nature, and God. I was shorn of my branches, which had waved in sympathy and love for home and friends. The natural coat of bark which had protected my oversensitive nature was scraped off to the very quick. Now a cold bare pole I seemed to be, planted in a strange earth. (99)

This simile is one of the last images Zitkala-Sa leaves with readers, in the final section of her final essay for the Atlantic Monthly. This placement gives the simile added import, and benefits from the setup of the telegraph poles in "School Days." Like Chesnutt, Zitkala-Sa figures her break in the bond with her ancestors in terms of a break with, first and foremost, her maternal roots. Also like Chesnutt, her writing here illustrates the depth and degree of violence inherent to the project of assimilating indigenous people into white society, a process where "persons and property, humans and things, blur into each other and bear the brunt of the master's [or paleface's] intractable violence" (Tyler 40). Visually, the description of the scraped-off bark evokes the process of losing one's color, a figurative strategy similar to Chesnutt's de-barking of the pine tree for turpentine. Last, Zitkala-Sa returns to the image of the "bare pole," which hearkens back to the hurt, moaning telegraph poles she listened to as a child.

While on the surface this final image is bleak, it also works on a deeper, more hopeful level. In Chesnutt's "Po' Sandy," for example, the pine tree goes on after its brutal dismemberment at the sawmill to be a kitchen, then a schoolhouse, and finally a church. According to Trent Masiki, Sandy's transformation "suggests that the body is ultimately a temple," and that his "transformative chain of being promotes a radical politics of optimism and endurance...there is no death; there is only change" (372). As long as the spirit of Sandy haunts and inhabits the material world, it evades death. He is not annihilated, then, so much as metamorphosized into something else.

Likewise, Zitkala-Sa's vision of herself as telegraph pole can be read not only as an expression of her deep pain and spiritual suffering, but also as her powerful transformation into something else. No longer a child, she has become a telegraph pole, moaning in pain but still a living part of the world. She has escaped annihilation by changing into a bare pole, a vulnerable conduit, and just as Sandy's reconfiguration into a church can be read as emphasizing the importance of community and spiritual solidarity (Masiki 372), Zitkala-Sa's transformation into a telegraph pole can be read as a testament to the importance of communication and connectedness across the land. "Still," she writes. "I seemed to hope a day would come when my mute aching head, reared upward to the sky, would flash a zigzag lightning across the heavens" (99). 
Beautifully poetic and visually precise, this language evokes both the natural power of lightning and the crisscrossed electrical lines supported by telegraph poles, carrying their messages across the country. By visualizing herself as a component of this system, a bearer of messages, Zitkala-Sa imagines an important place for herself, an important role for her pain to play in the unfolding of the country's story. She will stand tall, head "upward to the sky," as she sends her messages outward across great distances of time and space.

At a moment in our nation's history when our ability to empathize with others is so compromised, and when so many are under threat of being made rootless through deportations and climate-change related migrations, it's more important than ever that scholars rethink the scope of narrative techniques that they are sensitive to in regionalist texts. Rather than looking to the works of writers like Zitkala-Sa and Charles Chesnutt for elements of the nostalgia present in Jewett's Country of the Pointed Firs, for example, or equivocating over whether or not they "fit" into a regionalist framework, scholars should widen their lens and examine the way these writers figure the exploitation, pain and rootlessness of the marginalized characters they represent in their work. Techniques that are effective, like Zitkala-Sa and Chesnutt's powerful images of the self-as-tree, ought to be centered in discussion of regionalist fiction rather than relegated to the ambiguous margins of the genre if we intend to learn from their example. For, as Zitkala-Sa says, "few there are who have paused to question whether real life or long-lasting death lies beneath this semblance of civilization" (99); however, those few questioners alive today - perhaps writing about the rootless and vulnerable populations within the modern nation-deserve access to the brave work and insights of the questioners that came before. 
Works Cited

Chesnutt, Charles W. Conjure Tales and Stories of the Color Line, edited by William L. Andrews, Penguin, 1992.

Di Silvestro, Roger and Shirley Boteler Mock. "Freedom Train." Americas, vol. 52, no. 6, Nov./Dec. 2000, p. 22. EBSCOhost, ezproxy.uno.edu/login?url=http://search.ebscohost.com/ login.aspx ?direct=true $\& d b=a 9 h \& A N=3768090 \&$ site $=$ ehost-live \&scope=site.

Fetterley, Judith, and Marjorie Pryse, editors. American Women Regionalists. Norton, 1992.

Hafen, P. Jane. "'Help Indians Help Themselves': Gertrude Bonnin, the SAI, and the NCAI." The American Indian Quarterly, no. 3, 2013, p. 199-218. EBSCOhost: 10.1353/aiq.2013.0041. Accessed 5 Dec. 2017.

Holman, David Marion. A Certain Slant of Light. Louisiana State UP, 1995.

Jewett, Sarah Orne. “The Circus at Denby.” American Women Regionalists, edited by Judith Fetterley \& Marjorie Pryse, Norton, 1992, pp. 187-197.

Kaplan, Amy. "Nation, Region, Empire." The Columbia History of the American Novel. $\quad$ New York: Columbia UP: 1991, pp. 240-66.

Masiki, Trent. "The Satyr, the Goddess, and the Oriental Cast: Subversive Classicism in Charles W. Chestnutt's 'The Goophered Grapevine' and 'Po' Sandy'." African American Review, vol. 49, no. 4, Winter 2016, pp. 361-383. EBSCOhost, ezproxy.uno.edu/login?url=http://search.ebscohost.com/login.aspx?di rect=true\&db=lfh\&AN=120460813\&site=eds-live\&scope=site.

Miller, Daegan. “Reading Tree in Nature's Nation: Towards a Field Guide to Sylvan Literacy in the Nineteenth-Century United States." American Historical Review, vol.

121, no. 4, Oct. 2016, pp. 1114-1140. EBSCOhost: ezproxy.uno.edu/ login?url=http://search.ebscohost.com/login.aspx?direct=true\& $\mathrm{db}=\mathrm{a} 9 \mathrm{~h} \& \mathrm{AN}=118646237 \&$ site=ehost-live\&scope=site. Accessed 5 Dec. 2017.

"Radical, Adj. and N." OED Online, Oxford University Press, June 2017, www.oed.com/view/Entry/157251. Accessed 5 December 2017.

Tunc, Tanfer Emin. "The De(Con)Struction of Black/White Binaries." Callaloo, vol. 37, no. 3, Summer 2014, pp. 676-691. 
Wilkerson, Isabel. Interview by Laine Kaplan-Levenson. TriPod Xtras, 16 Nov. 2017, http://wwno.org/post/tripod-xtras-isabel-wilkerson. Accessed 5 Dec. 2017.

Zitkala-Sa. "Impressions of an Indian Childhood" and "The School Days of an Indian Girl." American Women Regionalists, edited by Judith Fetterley \& Marjorie Pryse, Norton, 1992, pp. 535559.

-. “An Indian Teacher Among Indians." American Indian Stories. Hayworth Publishing House, 1921, pp. 81-99. 